International Journal of Instruction e-ISSN: 1308-1470 • www.e-iji.net

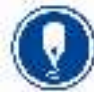

July $2021 \bullet$ Vol.14, No.3
p-ISSN: $1694-609 \mathrm{X}$
pp. 327-340

Article submission code: 20200430055847

Received: 30/04/2020

Revision: $17 / 12 / 2020$
Accepted: 10/01/2021

OnlineFirst: 17/05/2021

\title{
Development of the Evaluation Instrument of the Child-Friendly School Policy in Elementary Schools
}

\section{Mami Hajaroh}

Universitas Negeri Yogyakarta, Indonesia,mami_hajaroh@uny.ac.id

Rukiyati

Universitas Negeri Yogyakarta, Indonesia, rukiyati@uny.ac.id

Lusila Andriani Purwastuti

Universitas Negeri Yogyakarta, Indonesia, lusila_ap@uny.ac.id

\section{Riana Nurhayati}

Universitas Negeri Yogyakarta, Indonesia, riana_nurhayati@uny.ac.id

Policy evaluation is essential to determine the success of the policy implementation in achieving its objectives. For evaluation purposes, a set of valid and reliable instruments is needed in order for the data could describe the object being measured. It is necessary to use a child-friendly school assessment instruments (CFS-AI) when the child-friendly policy is implemented. This research aimed to develop a measurement instrument of child-friendly school policy and program in elementary school with the Context, Input, Process, and Product (CIPP) evaluation model. The research used a quantitative-qualitative approach as suggested by Onwuegbuzie (2010), which an assessment instrument developed with mixed-methods analysis. The sample of this research consist of teachers, principals, parents, and community members around the school. The data were analyzed by Exploratory Factor Analysis (EFA) using the SPSS program to determine the validity and reliability of an instrument. The results showed the child-friendly school assessment instrument (CFS-AI) developed in four assessment aspects has fulfilled the requirements of validity and reliability. It implies that CFS-AI has fullfilled the standards to measure the success of the implementation of child-friendly schools in elementary schools. This instrument is comprehensive, precise, and consistent to measure the implementation of childfriendly school policy.

Keywords: development, evaluation, instrument, child-friendly schools, elementary school

Citation: Hajaroh, M., Rukiyati., Purwastuti, L. A., \& Nurhayati, R. (2021). Development of the Evaluation Instrument of the Child-Friendly School Policy in Elementary Schools. International Journal of Instruction, 14(3), 327-340. https://doi.org/10.29333/iji.2021.14319a 


\section{INTRODUCTION}

Public policy is a government intervention to improve welfare. An evaluation is required to assess whether policies and programs affect the community welfare as well as the policy objectives. In the public sector, evaluation plays an important role in the policy process and policy planning. The two processes, according to Guyadeen \& Season (2018), follow these phases, namely: identification and problem definition, formulation, implementation, and evaluation. Evaluation in policy formulation and program implementation focuses on several policies and program impacts (Bell, 2017). Evaluation serves some purposes for enterprise development, such as: management checks, learning resources, and the basis for decision making (Grasso, 2010). Evaluation results can provide information about the success, efficiency, and effectiveness of policies and programs in improving the welfare of the community. The simplified evaluation process can be systematically completed in-house and will help program administrators and staff identify issues more timely than traditional evaluation (Perez \& Zerena, 2016). In recent years, evaluation studies have focused on broader and more inclusive impacts on the assessments instead of merely incorporating findings from policy and program development. The evaluation results are useful for the government to make decisions and some further policies.

\section{Literature Review}

\section{Policy Evaluation}

There are two approaches used in policy evaluation, namely: formal and informal approaches. Both have advantages and disadvantages. Moreover, there is also a. hierarchical and polycentric evaluation approach (Schoenefeld \& Jordan, 2017). The evaluation is divided into two types: program and planning evaluations (Guyadeen \& Season, 2018). Both share similarities in some ways but are also different in some other means. Both approaches are based on the principles of resource management to produce tangible benefits. Planning evaluation is used to improve the quality, the implementation, the process, and the effectiveness of the plans.

Evaluation of education policy is one of the essensial issues in policy research in the Asia Pacific region as written in the study of Jeong, et al. (2014) which seeks to find out what educational policy issues are the focus of attention in the Asia-Pacific context. Jeong, et al. (2014) examined the publication data of Asia-Pacific research from the Web of Science, found several facts namely: (1) increasing research collaboration, (2) developing policy evaluation research, (3) developing empirical research with quantitative methodologies and (4) developing pay attention to higher education. The issue of evaluation is that in Asia-Pacific countries, it has been understood as an increasingly important issue for enhancing teacher professional development.

Program evaluation is broadly defined as a systematic assessment of the process and or outcomes of a program, compared to a set of explicit or implicit program standards (Weiss, 1998). Program evaluation serves as a means to contribute to program improvement .It is necessary to systematically assess the program by following acceptable rules of social science research (Rossi \& Howard: 1985). Furthermore, it is 
needed to develop measurement instruments in order to obtain reliable information (Kantanen, et al, 2015). The validity of the instrument is important to conduct, especially in education and psychology, as it is the basis for any latent construct measurement efforts a related field (Raykov, Marcoulides \& Li, 2016).

Therefore, in evaluation, it is necessary to develop a set of measurement instruments that are valid and reliable so that the data obtained can provide a real picture of the object being measured and evaluated or in the other word one aspect of education policy evaluation research is developing evaluation instruments that meet the validity and reliability standards. Idris (2017) examined the development and validation of instruments to measure the statistical conception of Indonesian pre-service teachers using the mixed method. Fan, et al. (2018) developed a valid and reliable scale to measure Chinese physical education teacher's beliefs about the physical education profession (PPET-BPEP). The research conducted by Gan, et al. (2019) presented the development and validation of strong psychometric assessment measures for learning experiences in Chinese higher education is an Assessment for Learning Experiences Inventory (AFLEI). The instrument validation done by Gan, et al. (2019) uses Exploratory Factor Analysis and Confirmatory Analysis.

One of the approaches in developing the instrument and construct validation is the quantitative-qualitative approach of Onwuegbuzie (2010) model which includes ten stages (Onwuegbuzie, et al., 2010; Daigneault \& Jacob, 2014; Koskey et al., 2018), namely: 1) conceptualize the construct of interest, 2) identify and describe behaviors that underlie the construct, 3) develop initial instrument 4) pilot-test initial instrument, 5) validate revised instrument: dominant crossover analyzes, 6) validate revised instrument through mixed analysis phase (quantitative-dominant crossover analysis), and 10) evaluate the instrument development construct evaluation process and product.

\section{Child-Friendly School Policy}

The Child-Friendly School Policy (CFS) was launched by UNICEF in 2006 (UNICEF, 2006). Indonesia ratified this policy by issuing the Ministry of Women's Empowerment and Child Protection of Republic of Indonesia, number 8 the year 2004, on ChildFriendly School (The Ministry of Women Empowerment \& Child Protection, 2014). This policy demonstrates the serious attention to school convenience that children need. Children prefer to be in a comfortable school with a variety of activities that which could boost their achievements. The legal basis of the CFS policy is contained in the 1945 Constitution of Article $28 \mathrm{C}$ which states: "Everyone has the right to develop themselves through the fulfillment of basic needs, entitled to education and benefit from science and technology, arts and culture, to improve the quality of his life and for the welfare of mankind".

In the child-friendly school development policy guideline, it is important to monitor, evaluate, and report the implementation of the policy. The results of monitoring and evaluation can be the basis for making decisions and improving the quality of subsequent child-friendly school policies. In education, evaluation has proven to be a useful tool for ensuring the quality of education. Evaluation serves as a 'mirror' that 
reflects the state of the implementation of education, institutions, programs, or individuals in the education system (Ansah, 2010). Also, evaluation can be used to assess the effectiveness of established programs, such as assess whether the program has achieved its objectives and/or affect the students. The CFS evaluation aims to assess the effectiveness, efficiency, and efficacy of the program with expectations (UNICEF, 2006). The evaluation results may have an affect on government policy (UNESCO, 2014). Therefore, the evaluation of CFS depends on the last users and the expectations that have been made.

On the one hand, the last users may be only interested to know whether the program can achieve its objectives. On the other hand, they are interested in measuring the impact of the program. The evaluation intended in the implementation of the CFS refers to the monitoring and evaluation guidance of UNESCO, which is a periodic retrospective assessment of an organization, project or program that can be performed internally or by external independent evaluators (UNESCO, 2014).

A valid and reliable measurement instrument is required to develop in order to evaluate the implementation of the CFS program in Indonesia. Development of educational assessment instruments has been widely conducted, such as the misconception detection instrument matter of chemical bonds for the students developed by Salirawati \& Wiyarsi (2012). Another example is an instrument for assessing analytical thinking skills and chemical process science skills developed by Laksono, et al. (2017). However, the development of instruments for the purposes of evaluation of policies and programs is still not sufficient. Therefore, the child-friendly school assessment instrument (CFS-AI), which meets the validity and reliability standards is important to be developed so that the information obtained is reliable and agreed with the contracts measured.

In addition, in the program evaluation, it is important to determine the model of program evaluation following the needs of the evaluation. One of the most comprehensive program evaluation models is the context, input, process, and product (CIPP) model, which is the most widely used evaluation model by the evaluators. The four components of CIPP are basically the components of a program's process. The CIPP model is a model developed by Stufflebeam et al. in 1967 at Ohio State University (Arikunto \& Cepi, 2007). According to the CIPP concept, an important goal of the evaluation is not to prove, but to improve (Widoyoko, 2009). Evaluation of CFS program is important to do in order to know the extent the success of a program and know the aspects that must be improved. Therefore, it is essensial to develop a reliable and reliable child-friendly school assessment instrument (CFS-AI).

\section{METHOD}

\section{Design}

This research employed a development research design that aimed to develop ameasurement instrument of child-friendly school policy and program in elementary school. The development of the assessment instrument for the implementation of childfriendly school programs in primary schools called Child-Friendly School Assesment 
Instrument (CFS-AI) has used the Instrument Development and Contractivee Validation (IDCV) process with a CIPP evaluation model (context, input, process, and product) covering ten stages (Onwuegbuzie, et al., 2010). The detailed processes of Figure 1 are presented as follows:

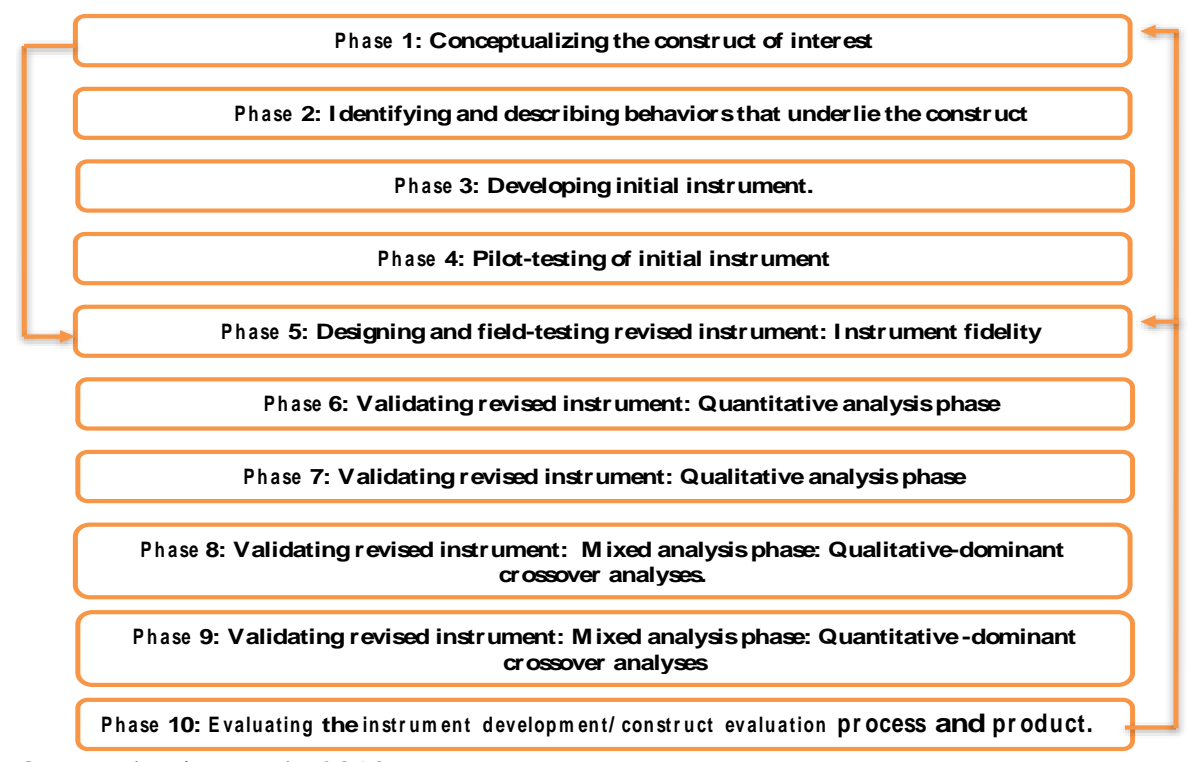

Onwuegbuzie, et. al., 2010

Figure 1

Instrument development and construct validation (IDCV) process

\section{Participants}

The Participants of this research were 314 people consisting of 31 principals, 186 teachers, 62 parents, and 35 community members in primary schools in Indonesia.

\section{Data analysis}

The data were analyzed by EFA (Exploratory Factor Analysis) using the SPSS program (Teguh, 2015). The result of the factor analysis was then used to determine the quality and reliability of an instrument. The purpose of factor analysis, according to Brown, is to explore the structure of variants and verify the patterns in a set of correlation coefficients (Brown, 2001). Factor analysis was used to identify elements underlying variables or factors that explain the correlation pattern in a set of variables or factors observed. In this study, factor analysis was used to identify items that underlie context, input, process and product variables from child-friendly school programs. 


\section{The Criterion of Validity and Reliability of Instrument}

The factor analysis criteria used for sampling suitability are to look at the score of $\mathrm{KMO} /$ Kaiser-Meyer-Olkin Measure of Sampling Adequacy. If KMO> 0.5, then the sampling used in this indicator test is appropriate. In addition to the KMO value, the appropriateness of the data in factor analysis can be seen in the matrix anti-image or anti-image correlation (Teguh, 2015). If the KMO number describes the overall suitability of the data, then the diagonal matrix of the anti-image correlation shows the suitability of the data for each item. If the correlation number shows $<0.50$, then the inclusion of items needs to be reconsidered. Bartlett's Test of Sphericity criteria was used to determine whether or not each item correlates low (towards zero) with another item, which could imply that each item is independent. For this purpose, the significance of $\alpha=0.5$ was used, and it was then compared with the significance of the calculation results.

Factor value is considered adequate if the correlation factor value is at the lowest $(0.32)$. Andrew suggested the category for F, i.e.: 0.7 - 1.0 (special), 0.45 - 0.69 (good enough), 0.32 - 0, 45 (medium), and <0.32 (bad), (Andrew:1973). Based on the criteria, the $\mathrm{F}$ value that is less than 0.50 was declared void. A similar or nearly identical $F$ score that contained more than one indicator was also declared void as it measured more than one theoretical dimension. In addition, the negative $\mathrm{F}$ value was declared void. The number of item communities indicates the amount of donated items to the measured variable. In terms of reliability, the instrument is called good if it has an $\alpha$ value of $0.6-0.8$ and the instrument is categorized very good if the value of $\alpha>0.8$. Total Variance Explained is useful to determine how many possible factors can be established. To determine the total Variance that has been established, the researchers used Eigen value. According to Nurosis (1986), eigenvalue $>1$ is a factor value that can be used as an indicator of a trait. If the cumulative percentage of the eigent value shows a number greater than 0.50 , it means that the indicators for a variable are said fulfilled (Nurosis:1986).

\section{FINDINGS}

The development of the assessment instrument for the implementation of child-friendly school programs in elementary schools is called the Child-Friendly School Assessment Instrument (CFS-AI). It was conducted through the Instrument Development and Construct Validation processusing the CIPP evaluation model (context, input, process, and product) and by following 10 stages as shown in the following figure 1 by Onwuegbuzie et al. (2010). The results of the 10 stages of development are presented below.

\section{Conceptualizing the construct of interest: literature interdisiplinary review}

The development of CFS-AI began with drafting a concept about child-friendly schools. At this stage, an analysis of variables and indicators of policies and child-friendly school programs in elementary schools was carried out. After that, the existing evaluation models were analyzed, and then a program evaluation model had been selected. From the analysis, the appropriate evaluation model chosen was the CIPP model (context, input, process, and product). This model can provide a comprehensive picture of the 
overall implementation of the program. The result of this model can provide sufficient information for school principals and stakeholders in developing policies for further programs.

Table 1

The results of the analysis on the item of context of CFS

\begin{tabular}{cclll}
\hline No. & CommunalityScore & Anti ImageMatrix & RotationMatrix & Factor \\
\hline 1 & 0.821 & $0.736^{\mathrm{a}}$ & 0.864 & 1 \\
\hline 2 & 0.509 & $0.759^{\mathrm{a}}$ & 0.567 & 1 \\
\hline 3 & 0.717 & $0.761^{\mathrm{a}}$ & 0.650 & 2 \\
\hline 4 & 0.789 & $0.598^{\mathrm{a}}$ & 0.864 & 2 \\
\hline 5 & 0.581 & $0.741^{\mathrm{a}}$ & 0.657 & 2 \\
\hline 6 & 0.579 & $0.810^{\mathrm{a}}$ & 0.547 & 3 \\
\hline 7 & 0.714 & $0.803^{\mathrm{a}}$ & 0.543 & 3 \\
\hline 8 & 0.755 & $0.682^{\mathrm{a}}$ & 0.829 & 3 \\
\hline 9 & 0.782 & $0.710^{\mathrm{a}}$ & 0.606 & 3 \\
\hline 10 & 0.779 & $0.621^{\mathrm{a}}$ & 0.636 & 4 \\
\hline 11 & 0.773 & $0.645^{\mathrm{a}}$ & 0.866 & 4 \\
\hline
\end{tabular}

The analysis result on the input aspect consisting of 12 items of the statement in the rotation matrix shows that the input variable has four components with the eigent value of 67.946. This means that the twelve points can explain $67.95 \%$ of the input aspects of CFS in elementary school. The instrument reliability by using Alpha Cronbach reaches the value of 0.789 . The analysis criteria shows that the input instruments of schoolfriendly school programs in primary schools were valid and reliable. The results of the analysis can be seen in table 2 .

Table 2

The results of the analysis on input of CFS

\begin{tabular}{cclcl}
\hline No. & CommunalityScore & Anti ImageMatrix & RotationMatrix & Factor \\
\hline 1 & 0.825 & $0.695 \mathrm{a}$ & 0.873 & 1 \\
\hline 2 & 0.690 & $0.716 \mathrm{a}$ & 0.575 & 1 \\
\hline 3 & 0.783 & $0.756 \mathrm{a}$ & 0.858 & 1 \\
\hline 4 & 0.553 & $0.736^{\mathrm{a}}$ & 0.670 & 2 \\
\hline 5 & 0.603 & $0.833 \mathrm{a}$ & 0.766 & 2 \\
\hline 6 & 0.667 & $0.786^{\mathrm{a}}$ & 0.656 & 2 \\
\hline 7 & 0.529 & $0.715^{\mathrm{a}}$ & 0.697 & 2 \\
\hline 8 & 0.697 & $0.680 \mathrm{a}$ & 0.683 & 3 \\
\hline 9 & 0.763 & $0.629 \mathrm{a}$ & 0.837 & 3 \\
\hline 10 & 0.628 & $0.878^{\mathrm{a}}$ & 0.600 & 3 \\
\hline 11 & 0.761 & $0.536 \mathrm{a}$ & 0.764 & 4 \\
\hline 12 & 0.654 & $0.510^{\mathrm{a}}$ & 0.779 & 4 \\
\hline
\end{tabular}

The rotation matrix in the process aspect shows that the process aspect consists of 4 components with an eigenvalue of 70,915. This means that the twelve items can explain $70.915 \%$ of the aspects of the context of CFS in Primary Schools. The process instrument has an Alpha Cronbach value of 0.800, which indicates that the CFS process instrument has a good reliability rate. These criteria show that the instrument input for a 
child-friendly school program in elementary school was valid and reliable to be used as a measuring tool. The results of the analysis can be seen in table 3 .

Table 3

The results of the analysis on the item of process of CFS

\begin{tabular}{ccccl}
\hline No. & CommunalityScore & Anti ImageMatrix & RotationMatrix & Factor \\
\hline 1 & 0.798 & $0.733^{\mathrm{a}}$ & 0.781 & 1 \\
\hline 2 & 0.807 & $0.732^{\mathrm{a}}$ & 0.880 & 1 \\
\hline 3 & 0.738 & $0.747^{\mathrm{a}}$ & 0.762 & 1 \\
\hline 4 & 0.751 & $0.734^{\mathrm{a}}$ & 0.851 & 2 \\
\hline 5 & 0.654 & $0.807^{\mathrm{a}}$ & 0.758 & 2 \\
\hline 6 & 0.626 & $0.682^{\mathrm{a}}$ & 0.573 & 3 \\
\hline 7 & 0.770 & $0 . .684^{\mathrm{a}}$ & 0.825 & 3 \\
\hline 8 & 0.759 & $0.562^{\mathrm{a}}$ & 0.822 & 3 \\
\hline 9 & 0.681 & $0.731^{\mathrm{a}}$ & 0.777 & 3 \\
\hline 10 & 0.721 & $0.673^{\mathrm{a}}$ & 0.793 & 4 \\
\hline 11 & 0.705 & $0.776^{\mathrm{a}}$ & 0.783 & 4 \\
\hline
\end{tabular}

Eight points on the impact/product aspect had the eigen value of 70,915, meaning that 8 points can explain $70,915 \%$ of the aspects of the impact of the CFS in the Elementary School. The results also show the Alpha Cronbach value of 0.800 , indicating that the CFS impact instrument has good reliability. The rotation matrix indicates that the impact aspect consists of 4 components. This instrument was valid and reliable so that it can be used as a measuring tool for the impact of child-friendly schools in elementary schools. The results of the analysis can be seen in table 4 .

Table 4

The results of the analysis on the item of productof CFS

\begin{tabular}{cclcl}
\hline No. & CommunalityScore & Anti ImageMatrix & RotationMatrix & Factor \\
\hline 1 & 0.807 & $0.801^{\mathrm{a}}$ & 0.880 & 1 \\
\hline 2 & 0.738 & $0.755^{\mathrm{a}}$ & 0.762 & 1 \\
\hline 3 & 0.751 & $0.743^{\mathrm{a}}$ & 0.851 & 2 \\
\hline 4 & 0.626 & $0.575^{\mathrm{a}}$ & 0.573 & 3 \\
\hline 5 & 0.770 & $0 . .619^{\mathrm{a}}$ & 0.825 & 3 \\
\hline 6 & 0.759 & $0.718^{\mathrm{a}}$ & 0.822 & 3 \\
\hline 7 & 0.721 & $0.823^{\mathrm{a}}$ & 0.793 & 4 \\
\hline 8 & 0.807 & $0.801^{\mathrm{a}}$ & 0.880 & 1 \\
\hline
\end{tabular}

Evaluating the instrument development/construct evaluation process and product

Child-friendly school assessment instruments (CFS-AI) have good face validity, item validity, results in validity, generalization, and structural validity. This instrument can be used to measure the success of child-friendly school programs in primary schools. However, it would be better if the instrument is used on a wider scale and then reanalyzed for further improvement.

\section{DISCUSSION}

Measuring aspects of context relates to measuring aspects of needs, assets, and problems in defining a program. Instrument aspects of the context of CFS are related to the 
process of analyzing the problem of education in coastal areas, the formulation of educational problems in coastal tourism areas, the vision and mission of the school, and the infrastructure of the CFS in educational units. In this aspect of context, 11 items are arranged, as presented in table 5 .

Table 5

Items on context aspects of CFS

\begin{tabular}{clc}
\hline No. & \multicolumn{1}{c}{ Question items } & F value \\
\hline 1 & Vision and Missionsof the schoolare agreed with the indicators CFS & 0.821 \\
\hline 2 & The teacher recognizes the background issues and characteristics of the learner. & 0.509 \\
\hline 3 & $\begin{array}{l}\text { Schools have the infrastructure in schools that support the implementation of } \\
\text { CFS. }\end{array}$ & 0.717 \\
\hline 4 & There is a logo/slogan related to CFS at school. & 0.789 \\
\hline 5 & Schools have financial support for the implementation of the CFS. & 0.581 \\
\hline 6 & $\begin{array}{l}\text { The school makes annual CFS policies and programs at the beginning of each } \\
\text { year. }\end{array}$ & 0.579 \\
\hline 7 & $\begin{array}{l}\text { CFS development policies and programs are related to meeting the needs of } \\
\text { child-friendly schools. }\end{array}$ & 0.714 \\
\hline 8 & School goals are following the vision of the school's mission to achieve the CFS. & 0.755 \\
\hline 9 & The school involves parents' stakeholders in deciding the CFS policy. & 0.782 \\
\hline 10 & $\begin{array}{l}\text { There is good cooperation among parents, community, and schools in } \\
\text { implementing CFS policies and programs. }\end{array}$ & 0.779 \\
\hline 11 & Schools have so far been disciplined to realize the CFS. & 0.773 \\
\hline
\end{tabular}

The school's vision and mission contain important values in the aspect of the context of child-friendly schools. School values that are in accordance with indicators of childfriendly schools become the orientation and guide the realization of a child-friendly school (CFS). This vision and mission will be explained in the policy making and annual program of child-friendly schools at the beginning of each year. The CFS development policies and programs prepared by the school must be in line with the fulfillment of CFS needs. The values that exist in the vision and mission are elaborated in the rules in the form of rules. Order is needed to support the realization of policies and programs. Rules of conduct are also used as signs of program implementation. Teachers, facilities, infrastructure and financial support, are important factors in the context aspect. The teacher is the spearhead of the implementation of the CFS teaching and learning process. This is in line with one of the five basic principles of CFS, namely learner-centered learning. Facilities, infrastructure, and financial support are material resources in implementing school policies (Hajaroh, et al. 2017). The CFS policy uses the concept of school-based management, so that participation and collaboration with parents, school committees, and the community are needed in the formulation and implementation.

An instrument on the input aspect relates to the measurement on aspects of the selection of approaches in strategy, such as the strategy in making work plan and budget, the strategy of formulation of policy and program, the strategy in organizing, the implementation strategy, the resource strategy, and the financing strategy of CFS. There are 12 items in the input aspect, as presented in the following table 6. 
Table 6

Items on input aspects of CFS

\begin{tabular}{cll}
\hline No. & Question Items & F value \\
\hline 1 & Teachers / parents / principals have their own strategies in implementing CFS. & 0.825 \\
\hline 2 & Organizing in the implementation of programmed CFS policies well. & 0.690 \\
\hline 3 & $\begin{array}{l}\text { Schools involve parents in supporting funding for the implementation of the } \\
\text { CFS program. }\end{array}$ & 0.783 \\
\hline 4 & Schools have some ways of formulating CFS policies and programs. & 0.553 \\
\hline 5 & Schools have clear work procedures related to the implementation of the CFS. & 0.603 \\
\hline 6 & Schools conduct HR development activities for teachers related to CFS & 0.667 \\
\hline 7 & Teachers have equal opportunities to develop an understanding of CFS. & 0.529 \\
\hline 8 & $\begin{array}{l}\text { Schools are reporting the use of budgets related to the implementation of the } \\
\text { CFS program. }\end{array}$ & 0.697 \\
\hline 9 & $\begin{array}{l}\text { Schools seek funding with the community, foundations and school committees } \\
\text { for CFS. }\end{array}$ & 0.763 \\
\hline 10 & Schools have plans to accept children from different backgrounds. & 0.628 \\
\hline 11 & Teachers are involved in the formulation and implementation of CFS. & 0.761 \\
\hline 12 & Parents understand the policies and programs of CFS. & 0.654 \\
\hline
\end{tabular}

The researchers also measured the aspects of the process related to the measurement of the implementation of the CFS program, such as: habituation, civilization about life and environment clean, democratic, and education-oriented towards the development of students' potentials. The implementation also involved three education centers, namely schools, parents, and the community. In this process variable was arranged into 11 items, as presented in table 7.

Table 7

Items on process aspect of CFS

\begin{tabular}{lll}
\hline No. Question Items & F value
\end{tabular}

$1 \quad$ Teachers, together with students, maintain environmental cleanliness and 0.798 preserve the environment.

$2 \quad$ Teachers are obliged to shake hands and greet each other with students and 0.807 fellow teachers every morning, and every time the class is dismissed.

\begin{tabular}{lll}
\hline 3 & Each class has a class officer chosen by the students by deliberation. & 0.738
\end{tabular}

$4 \quad$ Schools cultivate environmental hygiene as a smoke-free, waste-free, and 0.751 alcohol-free area.

\begin{tabular}{lll}
\hline 5 & Activities at school strongly support students' self-development. & 0.654
\end{tabular}

$\begin{array}{lll}5 & \text { Schools identify physical, artistic, and intellectual abilities to provide mentoring } & 0.626\end{array}$ according to students' abilities.

\begin{tabular}{lll}
\hline 7 & Learning takes care of students' interests and talents. & 0.770
\end{tabular}

\begin{tabular}{lll}
\hline 8 & The teacher gives students an assessment after confirmation ofthe students. & 0.759
\end{tabular}

9 Classroom rules are created and determined by students with teacher 0.681 supervision.

$10 \quad$ Schools facilitate meetings with parents about parenting patterns that can 0.721 develop student potential.

\begin{tabular}{llc}
\hline 11 & Students feel at home in school. & 0.705 \\
\hline
\end{tabular}


The researchers measured the impact aspect relates to the measurement aspects of knowledge and behavioral change in parents, school culture, school teacher habits. In this context variable, eight items are arranged as in table 8.

Table 8

Items impact of CFS

\begin{tabular}{clc}
\hline No. & Question items & F value \\
\hline 1 & Parents are increasingly positive about their children. & 0.807 \\
\hline 2 & Parents engage in child-friendly success. & 0.738 \\
\hline 3 & School culture is very supportive of the cultivation of moral values. & 0.751 \\
\hline 4 & The teacher never yells and scolds students. & 0.626 \\
\hline 5 & Students feel safe and comfortable in school. & 0.770 \\
\hline 6 & Parents better understand their children. & 0.759 \\
\hline 7 & Moral values are already integrated into the child. & 0.721 \\
\hline 8 & $\begin{array}{l}\text { Parents understand the importance of feeling comfortable for children at } \\
\text { home. }\end{array}$ & 0.807 \\
\hline
\end{tabular}

The development of child-friendly school measurement instruments (CFS-AI) for the evaluation of child-friendly school policies and programs with this valid and reliable. CIPP model was used to measure the success of child-friendly school policies and programs in elementary schools. Instruments in context, input, process, and product components were valid according to the value of KMO, barlet test, eigent value, and factor values. The measurement of four aspects of the instruments indicated that this instrument was reliable to measure the success of child-friendly school policies and programs. However, these instruments need to be re-tested extensively by taking samples in other areas with larger sample quantities.

The development of the same types of instruments has been carried out by Brady, et al. (2008) who have developed self-evaluation instruments; Teguh (2010) has developed a self-evaluation instrument for academic programs to support work performance and needs; Phillips (2011) has developed an instrument to measure internal HIV/AIDS stigma; Carey, et al. (2014) have developed instruments for measuring the use of students' academic successful skills. While Lopez, et al. (2015) have developed an instrument to measure the success of the Youth Development (Positive Youth Development Measure) program. Carrington, et al. (2015) have developed instruments to measure the unintended consequences of HER (electronic health records). Grasso (2010) describes some factors of an effective evaluation for a development project, namely: 1. a positive policy environment in which evaluation addresses current policy issues; 2 . setting the evaluation time to meet the clear information needs of decisionmakers; 3 . adapting the evaluation to the context in which it will be used, and 4 . building relationships with clients, and effectively communicating evaluation findings.

\section{CONCLUSION}

The findings of this study are in line with several previous studies regarding the development of assessment instruments. This study shows that the child-friendly school assessment instrument (CFS-AI) developed in 4 aspects of assessment has fullfilled the validity and reliability requirements, so that CFS-AI has met the standards for 
measuring successful implementation of child-friendly schools in elementary schools. This instrument is comprehensive, precise, and consistent to measure the implementation of child-friendly school policies in Indonesia.

\section{REFERENCES}

Andrew, L. C. (1973). A First Course on Factor Analysis. New York: Academic Press, Inc.

Ansah, F., (2010). Designing self-evaluation instruments for academic programmes: Lessons and challenges. Evaluation and Research in Education, 23(2), 77- 90. https://doi.org/10.1080/09500791003717238.

Arikunto, S., \& Cepi. S.A., (2007). Evaluasi program pendidikan, pedoman teoretis praktis bagi praktisi pendidikan. Jakarta: Bumi Aksara.

Bell, D.A. (2017). Evaluation influence, the evaluation event and capital flow in international development. Evaluation Review, 41(6), 568-592. . https://doi.org/10.1177/0193841X17740028.

Brady, M. P., Rosenberg, H., \& Frain, M.P. (2008). A self-evaluation instrument for work performance and support needs. Career Development for Exceptional Individuals Journal, 31(3), 175-185. https://doi.org/10.1177/0885728808327150

Brown, J.D. (2001). What is an eigenvalue?Shiken: JALT Testing \& Evaluation SIG Newsletter, 5(1) 15-19, Retrieved from http://hosted.jalt.org/test/PDF/ Brown10.pdf.

Carey, J., Brigman, G., Webb, L., Villares, E, \& Harrington, K. (2014). Development of an instrument to measure student use of academic success skills: An exploratory factor analysis. Measurement and Evaluation in Counseling and Development, 47(3), 171-180. https://doi.org/10.1177/0748175613505622

Carrington, J.M., Gephart, S.M., Verran, J.A., \& Finley, B.A. (2015). Development of an Instrument to Measure the Unintended Consequences of EHRs. Western Journal of Nursing Research, 37(7), 842-858. https://doi.org/10.1177/0193945915576083

Daigneault, P.M. \& Jacob, S. (2014). Unexpected but Most Welcome: Mixed Methods for the Validation and Revision of the Participatory Evaluation Measurement Instrument. Journal of Mixed Methods Research, 8(1). 6-24. https://doi.org/10.1177/1558689813486190.

Fan, Y., Keating, X. D., Liu, J., Zhou, K., Shangguan, R., \& Knipe, R. (2018). Development of a Scale Measuring Chinese Preservice Physical Education Teachers' Beliefs About the Physical Education Profession. Asia-Pacific Education Researcher, 27(5), 365-372. https://doi.org/10.1007/s40299-018-0395-0

Gan, Z., He, J., \& Mu, K. (2019). Development and Validation of the Assessment for Learning Experience Inventory (AFLEI) in Chinese Higher Education. The Asia-Pacific Education Researcher Journal, 28, 371-385. https://doi.org/10.1007/s40299-01900435-7 
Grasso, P.G. (2010). Ethics and Development Evaluation: Introduction. American Journal of Evaluation, 31(4), 533-539. https://doi.org/10.1177/1098214010373647.

Guyadeen, D., \& Season, M. (2018). Evaluation theory and practice: Comparing program evaluation and evaluation in planning. Journal of Planning Education and Research, 38(1), 98-110. https://doi.org/10.1177/0739456X16675930.

Hajaroh, M., Rukiyati, Andriani, L., \& Saptono, B. (2017). Analisis Kebijakan Sekolah Ramah Anak di Kawasan Pesisir Wisata (Policy analysis of child-friendly school in coastal area of tourism). Yogyakarta: Andi Ofset.

Idris, K., \& Yang, K.L., (2017). Development and Validation of An Instrument To Measure Indonesian Pre-Service Teachers' Conceptions Of Statistics. Asia-Pacific Education Researcher, 26(5), 281-290. https://doi.org/10.1007/s40299-017-0348-z

Jeong, D.W., Lee, H.J., Ho, L.S., \& Eunjoo, W., (2014). Shaping education policy research in an Asia-Pacific context. Asia Pacific Education Review, 15, 367-380. https://doi.org/10.1007/s12564-014-9341-X

Kantanen, K., Kaunonen, M., Helminen, M., \& Suominen. T., (2015). The development and pilot of an instrument for measuring nurse managers' leadership and management competencies. Journal of Research in Nursing, 20(8). 667-677. https://doi.org/10.1177/1744987115605870.

Koskey, K. L. K., Sondergeld, T.A., Stewart, V.C., \& Pugh, K.J. (2018). Applying the mixed methods instrument development and construct validation process: The Transformative Experience Questionnaire. Journal of Mixed Methods Research, 12(1). 95-122. https://doi.org/10.1177/1558689816633310.

Laksono, E.W., Rohaeti, E., Suyanta, \& Irwanto. (2017). Penilaian Kemampuan Berpikir Analitis Dan Keterampilan Proses Sains Kimia. Jurnal Kependidikan, 1(1), 100-110.

Lopez, A., Yoder, J.R., Brisson, D., Lechuga-Pena, S., \& Jenson, J.M. (2015). Development and Validation of a Positive Youth Development Measure: The BridgePositive Youth Development. Research on Social Work Practice, 25(6), 726-736. https://doi.org/10.1177/1049731514534899.

Ministry of Women Empowerment \& Child Protection of Republic of Indonesia. (2014). Kebijakan Pengembangan Sekolah Ramah Anak (Policy of School-Friendly School). Jakarta.

Norusis, M. (1986). The SPSS guide to data analysis. Chicago, IL: SPSS, Inc.

Onwuegbuzie, A.J., Bustamante, R.M., \& Nelson, J.A. (2010). Mixed research as a tool for ceveloping quantitative instruments. Journal of Mixed Methods Research, 4(1), 5678. https://doi.org/10.1177/1558689809355805.

Perez, J. L., \& Zerena, A. (2016). Evaluating the policy-practice gap in a transitional housing program: An innovationin process evaluation. American Journal of 
Evaluation, 1-19. https://doi.org/10.1177/1098214015617730.

Phillips, K. D. (2011). Conceptual development of an instrument to measure the internalized stigma of aids based on the roy adaptation model. Nursing Science Quarterly, 24(4), 306-310. https://doi.org/10.1177/0894318411419222.

Raykov, T., Marcoulides, G. A., \& Li, T. (2016). Evaluation of Measurement Instrument Criterion Validity in Finite Mixture Settings. Educational and Psychological Measurement, 76(6), 1026-1044. https://doi.org/10.1177/0013164415613542.

Rossi, P., \& Howard. E. F. (1985). Evaluation systematic approach. California: Sage Publication.

Salirawati, D., \& Wiyarsi, A. (2012). Pengembangan Instrumen Pendeteksi Miskonsepsi Materi Ikatan Kimia Untuk Peserta Didik. Jurnal Kependidikan, 42(2), 118-129.

Schoenefeld, J., \& Jordan, A. (2017). Governing policy evaluation? Towards a new typology. Journal Evaluation, 23(3), 274-293. https://doi.org/10.1177/1356389017715366

Teguh S., A. (2015). Factor analysis theory (multivariate data analysis, research and statistics). Retrieved from http://menrvalab.com/analisis-faktor.

UNESCO. (2014). A step by step guide to monitoring and evaluation. This resource was developed as part of the Project' Monitoring and Evaluation for Sustainable Communities. Retrieved from http://www.geog.ox.ac.uk/research/ technologies/projects/monitoringandevaluationhtml.

UNICEF. (2006). Child Friendly School Manual. New York. Retrieved from https://www.unicef.org/publications/files/Child_Friendly_Schools_Manual_EN_040809 .pdf

Weiss, C. (1998). Evaluation. Upper Saddle River, NJ: Prentice Hall.

Widoyoko, E.P. (2009). Evaluasi Program Pembelajaran, Panduan Praktis Bagi Penddik dan Calon Pendidik (Evaluation of learning programs, practical guidelines for educators and prospective educators). Yogyakarta: Pustaka Pelajar. 